\title{
ЕЛІПТИЧНІ РЕЧЕННЯ ЯК ЗАСІБ ВИРАЖЕННЯ ЕМОЦІЙ (на матеріалі оповідання Б. Рейман “Die Geschwister”)
}

У статті висвітлено синтаксичний рівень вербалізащії емоцій психічної категорії. Виокремлено два різновиди еліптичних конструкиій: без головних та другорядних членів речення. Еліпсис визначено як специфічний тип висловлювання з пропущеним елементом, що тегко домислюється з контексту. 3'ясовано, що функиї еліпсисів корелюють з авторським та персонажним мовленням, опосередковуються суб'єктивною оцінкою. Авторське мовлення має гетерогенний (оповідь, опис, розмірковування), персонажне - гомогенний (діалог, полілог) характер. Парадигма емочій авторки обмежена негативними, персонажів - негативними, позитивними, нейтральними переживаннями та апелює до амбівалентних, негативних і позитивних емоційних патернів.

Ключові слова: емочії, еліптичне речення, авторське мовлення, персонажне мовлення, емоційний патерн, переживання.

Romanova N. Elliptic Sentences as a Means of Expression of Emotions (Based on B. Reimann's Story "Die Geschwister"). The article deals with establishing special aspects of expression of human emotions of the mental category at the grammatical level in modern German fiction. Emotion is defined by C. Izard as a fundamental personal process that gives meaning and significance to human existence. The relevance of our study is due to the anthropocentric focus of modern linguistics on the analysis of the relationship of language with emotional thinking, which allows determining the features of the creation of emotional meaning of a word, phrase, sentence, text. The aim of this article is to clarify the paradigm of human emotions at the syntactic level through German elliptical sentences. An elliptical sentence is an incomplete syntactic construction in which a certain element is omitted, which is easy to guess from the context. Achieving the goal involves a number of tasks: 1) to distinguish elliptical sentences in the empirical material; 2) outline the main functions of the analyzed language units; 3) to inventory human emotions on the basis of elliptical sentences of B. Reimann's story "Die Geschwister". An experimental card index of the phenomenon is compiled, the structural organization of ellipses as a syntactic means of expressing emotions of the mental category is analyzed, authorial and character incomplete emotional statements are differentiated, the main functions of ellipses with emotional meaning are outlined, emotions and emotional patterns are inventoried. The dominance of negative human experiences is proved. Based on the study, the following conclusions are drawn. The functions of the author's emotions are more diverse than the characters. Thus, the character experiences both emotions, and 
emotional patterns. The semantics of emotions and emotional patterns of characters are multifaceted: negative, positive, neutral, ambivalent. Preferences are identical to negative emotion and emotional patterns.

Key words: emotions, elliptical sentence, author's speech, character's speech, emotional pattern, experience.

\section{Вступ}

Емоції належать до специфічної форми взаємодії людини з навколишнім світом. Вони $є$ не лише психічним способом ії ставлення до соціуму, інших людей, самої себе, а й внутрішньою духовною мовою, системою сигналів, за допомогою яких можна дізнатися про те, що відбувається з нею (Изард, 2008).

Вираження людських емоцій, як відомо, корелює з культурою етносу, національною літературною мовою та емоціогенною ситуацією.

Існує дві системи вираження емоцій - соматична (невербальна) й лінгвістична (вербальна). Звичайно, ці системи в ході комунікації взаємодіють, доповнюють одна одну. Важливими чинниками $є$ також простір, у межах якого перебувають комуніканти, дистанція або відстань між ними, наявність натовпу або штовханини. Останні можуть перешкоджати міжособистісному спілкуванню або навіть унеможливлювати його (Бацевич, 2004: 66).

Дослідження соматикону простежуємо в працях I. Морозової (2009), М. Піменової (2007), I. Сєрякової (2012) та ін., лінгвістику феномену аналізують насамперед з позицій структурної та функціональної (Бабенко, 1989; Вежбицкая, 1999; Романова, 2013 та ін.), когнітивної (Гамзюк, 2000; Шаховский, 2008; Kövecses, 2004 та ін.), зіставної та прагматичної (Безугла, \& Романченко, 2013; Воркачев, 2003; Shevchenko, \& Gutorov, 2019 та ін.) семантики.

Мета пропонованої статті - з'ясування парадигми людських емоцій на синтаксичному рівні через німецькомовні еліптичні речення. Під еліптичним реченням розуміємо неповну синтаксичну конструкцію, у якій пропущено певний елемент, що легко домислити з контексту.

Досягнення мети передбачає розв’язання низки завдань: 1) виокремити еліптичні речення в емпіричному матеріалі; 2) окреслити основні функції аналізованих мовних одиниць; 3) інвентаризувати людські емоції на основі еліптичних речень оповідання Б. Рейман “Die Geschwister” («Сестра й брати»). 


\section{Методи дослідження}

У роботі використано низку загальнонаукових і спеціальних лінгвістичних методів. Загальнонаукові методи реалізуємо через принципи індукції, дедукції, аналізу й синтезу, спеціальні лінгвістичні - через структурний, семантичний, інтерпретаційно-текстовий, описовий аналізи. Встановлення критеріїв вибирання та виявлення особливостей побудови еліптичних речень здійснено гіпотетико-дедуктивним методом. Для систематизації основних функцій феномену застосовано структурно-семантичний аналіз. Специфіку смислового наповнення еліптичних речень розкрито через інтерпретаційно-текстовий аналіз та опис. За допомогою прийому тематичних груп виділено сукупність мовних одиниць, пов'язаних спільною темою (назви базових позитивних, негативних, нейтральних емоцій та емоційних патернів, назви емоцій (несхвалення, розчарування, жалкування, зневага, смуток, нудьга, образа, невдоволення, страх, хвилювання, роздратування, нетерпіння, гнів, несправедливість, провина, антипатія, осуд, агресивність, душевний біль (метафорично гіркота), інтерес, радість, подив, закоханість, ніжність, бажання, любов, сором, симпатія, каяття), безтурботність, спокій). Розмежування авторського та персонажного мовлення, а також інтенсивності вияву ними емоції або емоційного патерну грунтується на елементах концептуального аналізу.

\section{Виклад основного матеріалу}

Спостереження над експериментальною картотекою, укладеною методом суцільного вибирання, показує, що еліптичні речення трапляються як у мові авторки, так і в мові персонажів.

Авторка тотожна першій особі однини ich, Ich, наприклад: Als ich zur Tür ging, drehte sich alles in mir (Reimann, 2007: 5) і множини wir, Wir: Wir schliefen oft im Keller, Uli und ich auf einer Pritsche, und morgens sammelten wir die Silberpapierstreifen, die von den Amerikanern abgeworfen wurden (там само: 9), тобто ich, Ich впускає читача у свій внутрішній світ, бере відповідальність за всі оцінки й думки в оповіданні на себе (Романова, 2019: 76), wir, Wir, поєднуючи внутрішній («свій») і зовнішній («чужий») світи, об’єктивує зображення подій.

Персонажі - носії та противники авторських ідей - еквівалентні молоді, зокрема брати авторки: старший Konrad і молодший Uli 
(Ulrich), iї кохані чоловіки а) теперішній Joachim (ein fabelhafter Bursche), б) колишній Hans (Teuerster), однокласник Gregory, i, звичайно ж, сама авторка Lies, Elisabeth (для матері й Конрада), Betsy (для Ульріха), Elisabeth (для Йоахіма й Грегорі), Arendt, Fräulein Arendt (для колег і незнайомців). Інколи на передній план висувається старше покоління - батьки авторки або батьки ії коханих чи колеги-художники.

Такий поділ повної або офіційної форми жіночого імені Elisabeth "die Gott verehrt, Gottgeweihte" (Weitershaus, 1998: 147) на дві частини Lies і Betsy невипадковий. Він маніфестує, по-перше, різне ставлення братів до сестри (м’яке - суворе) і ії долі (позитивне - негативне), по-друге, характеризує самих братів (сентиментальний - брутальний), по-третє, вказує на особливість звукового складу імені (милозвучність - немилозвучність), по-четверте, десакралізує семантику антропоніма, по-п'яте, орієнтує адресата на емоційну оцінку з лінійкою «нейтральне - позитив - негатив».

Авторка вживає еліптичні речення, щоб охарактеризувати свій внутрішній стан, як-от наприклад: душевний біль Ich bin vierundzwanzig, Ø Ø ein Jahr jünger als er, und durch all die Jahre war mir sein Gesicht nah und vertraut - nur im letzten Jahr, seit den Sommerferien, wenn ich mich recht erinnere, fand ich zuweilen einen Ausdruck von Härte, der mir fremd Ø und quälend unverständlich blieb (Reimann, 2007: 6-7), щоб репрезентувати духовну близькість із любим братом Улі: Später konnten wir Andersens Märchen selbst lesen, Ø Ø gemeinsam, Ø Ø auf einer Fußbank dicht aneinandergerückt, und wir sahen die kleine Seejungfrau mit ihrem im Wasser treibenden langen Haar und rosigen Muscheln um den Hals und $\varnothing \varnothing$ die chinesische Nachtigall und $\varnothing \varnothing$ den Kaiser mit unendlich langen Fingernägeln und einem dünnen, gelben Schnurrbart, der ihm bis auf die Brust hängt (там само: 8), щоб створити емоційний образ пейзажу, на тлі якого проходило іiі дитинство: Blühende Kirschbäume Ø im Garten, der Sandkasten $\varnothing \varnothing$, die roten und gelben blechernen Förmchen $\varnothing \varnothing$; $\varnothing \varnothing$ eine mit Efeu bewachsene Mauer, an ihrem Fuß zwischen breitblättrigen, violett blühenden Klettenpflanzen sammeln wir Schneckenhäuser im feuchten, schwarzen Mulm; die Laube Ø im Garten eines Spielkameraden, dessen Namen ich vergessen habe, wir hocken im Heu, Ø spröder Duft $\varnothing$, wir rauchen getrocknetes Weinlaub in kurzen indianischen Tonpfeifen; $\varnothing \varnothing$ der Balkon, $\varnothing \varnothing$ Julihitze, $\varnothing \varnothing$ ein blauweiß gestreifter Sommerschirm, die grünen Blumenkästen Ø überwuchert von Petunien (там само: 7-8), щоб 
намалювати стисло портрет а) матері: Ø Ø ein Winterabend, meine Mutter, Ø rundlich und schwarzhaarig, Ø sitzt im Korbsessel vor ihrem mahagonibraunen Nähtischchen und Ø liest Andersens Märchen vor, hinter dem Fenster fällt die Dämmerung, es schneit ... (там само: 8), б) однієї з-поміж єврейок, у яких працювала мати до війни: Einmal kam eine Jüdin zu uns, um sich zu verabschieden. Sie trug einen gelben Stern auf dem Mantel und $\varnothing$ hatte krauses Haar, Ø Ø ganz grau, obgleich sie so jung war wie unsere Mutter (там само: 9), в) улюбленого квартиранта-окупанта з України: Er bringt Speck und $\varnothing \varnothing$ Weißbrot in die Küche. Manchmal zündet er auf dem Hof ein Holzfeuer an und $\varnothing$ brät Schaschlik - Ø $\varnothing$ Hammelfleisch und Tomaten und Zwiebelscheiben am Spieß -, und wir sitzen mit tränenden Augen im Rauch und Ø werfen die heißen, scharfgewürzten Fleischstücke von einer hohlen Hand in die andere. Wassilij hat jeden Abend Gäste. Irgendjemand spielt Ziehharmonika, stundenlang $\varnothing \varnothing$ dieselbe eintönige Melodie (там само: 11), г) неприязного квартиранта-окупанта з Pосії: Grischa hat einen schwarzen Schnauzbart und $\varnothing$ Ø schwere Augenlider, er sitzt da, $\varnothing$ raucht Pfeife, $\varnothing$ schweigt, $\varnothing$ raucht und $\varnothing$ starrt uns feindselig an (там само), г) батька, що повернувся з радянського полону: Ein Fremder $\varnothing$ in zerlumpter Uniform, der beim Sprechen mit der Zunge anstößt; nun soll man also "Vater" zu ihm sagen - er hat aber nichts zu tun mit dem heiteren jungen Mann, der uns früher Schokoladezigarren mitbrachte und Ø aus seinen Klubsesseln einen Wigwam für Winnetou und Mine-Haha baute (там само: 12), д) барменку: Die Barfrau Ø, hellblond und füllig, um die Augen und unterm Kinn $\varnothing \varnothing$ das Fleisch bleifarben und gedunsen, $\varnothing$ trug korallenrote Knöpfe im Ohr, und während sie Gläser spülte, erzählte sie uns Stadtklatsch, $\varnothing \varnothing$ vergnügt und ohne Bosheit (там само: 16), щоб відтворити динаміку а) радянської окупації: Die Offiziere bleiben Wochen, Ø Ø Monate, Ø Ø ein halbes Jahr ... (там само: 10), б) голоду: Wir haben Hunger. Meine Mutter verkauft Schmuck und $\varnothing \varnothing$ Bettwäsche und $\varnothing \varnothing$ die zierlichen alten Porzellanfigürchen aus dem Glasschrank (там само: 11), в) міжособистісних родинних стосунків (негативний сенс): Es gibt andere, die nicht mitgemacht haben. Aber ihr $\varnothing \varnothing$ : die Stellung, die Familie, die Existenz ... (там само: 13), г) кар'єрного росту: Nach der Währungsreform ging er als Arbeiter in ein Textilwerk, $\varnothing$ nahm ein Fernstudium auf, das er als Ingenieur-Ökonom abschloß, und $\varnothing$ ist heute Planungsleiter in eben jenem Textilbetrieb (там само: 14), г) психічних переживань: Ich horchte, sogar mit den Augen, Ø $\varnothing$ mit dem Mund, $\varnothing \varnothing$ mit den gespannten Schultern (там само: 15) тощо. 
Еліптичні речення в устах персонажів реалізуються більшою мірою через діалогічне, меншою через полілогічне спілкування. «Діалогічне спілкування передбачає ставлення до іншої людини як до цінності, неповторної індивідуальності» (Орбан-Лембрик, 2004: 349), полілогічне, охоплюючи трьох комунікантів (Романова, 2019: 29), висвітлює амбівалентне ставлення до людини - позитивно-негативне. Позитивними постають кревні родичі - брат Uli i сестра Betsy, коханці - чоловік Joachim і жінка Elisabeth, негативними духовно різні чоловіки - брат Ulrich і коханець Joachim. Маємо так званий «любовно-духовний трикутник» із сестрою-жінкою Betsy-Elisabeth на чолі. Сестра-жінка намагається примирити «своїх» чоловіків, тобто вона найбільш активний учасник комунікативного процесу. Будучи «недосвідченим дипломатом», вона пригнічує активність брата й заохочує пасивність коханця. Очевидним $€$ авторитарно-демократичний стиль полілогічного спілкування. Ми не можемо назвати цей стиль поганим чи вдалим, оскільки сестра-жінка визнає партнерів зі спілкування як рівнозначну цінність.

Наведемо приклади емоцій та емоційних патернів персонажів:

- несхвалення: "Aber wir zanken uns doch nicht." "Nenn's, wie du willst. Ihr diskutiert. Noch schlimmer" (Reimann, 2007: 16);

- інтерес: "Seit Weihnachten ist er Diplomingenieur", sagte ich. "Gute Stellung?” (там само: 19);

- розчарування: "Scheiße", sagte Uli (там само);

- радість: Ich lachte. "Die Faust im Nacken..." (там само: 20);

- жалкування: Hans gab mir die Hand, sie war kühl und trocken. "Schade" (там само: 21);

- безтурботність: “Gut gehen...”, wiederholte Hans und versuchte unbekümmert auszusehen (там само);

- гнів + подив: "Mach mir nichts vor, Mädchen, du kriegst ein Baby". "Quatsch", sagte ich, “woher denn?” (там само: 23);

- зневага, образа + погроза: ...und Uli stieß sich vom Tisch ab, er sagte zwischen den Zähnen: "Karrierist. Dickes Schwein ... Damals habt ihr mich nicht aufgenommen. Da wird euch noch leid tun..." (там само: 27);

- зневага: "Unternehmen", sagte Konrad verächtlich. "Muß ich bei einem Beamten um mein Recht betteln?” (там само: 34);

- смуток: “Tiefste Provinz", sagte Gregory (там само: 43);

- подив: "Übrigens habe ich deine politischen Ansichten immer respektiert." "So?" sagte ich (там само: 44); 
- нудьга: “Na und?”, fragte Konrad gelangweilt (там само: 53);

- образа: "Gar nicht”, sagte ich in gekränktem Ton (там само);

- невдоволення: Mein Vater sagte: “Aha, die Herren Kinder... Schon zu Haus..." (там само: 65);

- закоханість, ніжність: Er fuhr nur mit den Fingerspitzen meinen Augenbrauen nach, den Lippen, den Nasenflügeln, und ich bewegte mich nicht und sagte nichts, betäubt und zitternd unter einer Sturzsee von Empfindung, und nach einer sehr langen Zeit richtete sich Joachim auf und sagte: "Dein Gesicht... was für ein Abenteuer" (там само: 67);

- спокій: Joachim, mit seiner unverändert ruhigen Stimme, erwiderte: "Nur ein paar Zeilen für Felix... Felix ist mein Fahrer. Er wartet unten" (там само);

- нетактовність і приниження: "Mein Fahrer, mein Walzwerk, meine Arbeiter", höhnte Uli (там само);

- бажання: Auf der Treppe kehrte ich noch einmal um. "Umarme mich. Ganz fest" (там само: 68);

- любов + захоплення: Ich bedeckte seinen Hals und seine Schultern mit Küssen. "Mein Liebster. Mein Grauäugiger... mein wunderliches Nachbarskind..." (там само);

- страх: "Ich kann jetzt nicht nach Haus", sagte ich (там само: 70);

- інтерес + щастя: Joachim ließ den Koffer fallen. "Glücklich?” "Wahnsinnig". Ich warf mich in seine Arme (там само: 78);

- інтенсивність а) вихідного почуття: "Liebst du mich noch?”

"Unheilbar. Für immer und immer" (там само); б) хвилювання: "Nein", widersprach Uli, "nein, nein. Konrad ist doch auf der Deutschen Werft. Wir haben keine Verbindung” (там само: 83);

- роздратування: "Was glaubst du, wie wir uns geschafft haben. Dafür wird keiner geext, daß er Rosenmontag mal randaliert".

"Nicht bloß das", sagte Uli zwischen den Zähnen, er wurde von Sekunde zu Sekunde mürrischer (там само: 82);

- інтерес + нечутливість: “Was denn anrichten?” flüsterte ich, betäubt unter den gestammelten, von zurückgedrängter Empfindung halb gebrochenen Worten (там само: 84);

- нетерпіння: “Betsy!” sagte Uli ungeduldig. "Was ist? Was starrst du mich an?” (там само: 94);

- гнів: "Solange man für ihn kämpfen kann, solange er nicht von Schwachköpfen zerquatscht wird", schrie Uli. 
"Selber Schwachkopf", schrie ich. Wir standen uns gegenüber, rot und heiß, Ulis Augen funkelten, er warf seine Wut jetzt auf mich (там само: 98);

- несправедливість: "Jeden Tag Nadelstiche", sagte er, "das ist schlimmer als ein Dolchstoß. Mit der Ablehnung fing es an. Dann kam die Enttäuschung über die Arbeit auf der Neptunwerft. ‘...”" (там само: 104);

- сором: "Zieh dich bloß nicht darauf zurück, daß du Schmied bist".

"Ach, doch nicht deshalb", sagte er, und sein Gesicht färbte sich dunkel$\operatorname{rot}$ (там само: 112);

- симпатія: Ich sagte: "Lukas liebt Botticelli und Raffael, und bei meinem Meister hängen vier Modiglianis überm Bett"

"So, über seinem Bett", sagte Heiners mit einer sonderbaren Stimme (там само: 117);

- провина: ...und daß ich mich wie eine Beschuldigte fühlte und die Schuld auf meinen Vater abzuwälzen versuchte, und ich sagte rauh: "Und wenn... Mein Vater ist in Ordnung" (там само: 120);

- антипатія: "Na, lassen wir das, ich bin schon immer schwach in Theorie gewesen".

"Aber die Farben", beharte Heiners, “dieses Feuerwerk da..." (там само: 125 );

- осуд: "Kindskopf", sagte der Meister. Er spazierte in seiner Bude herum, mit dem leichten, graziösen Zehenschritt sehr korpulenter Leute (там само: 132);

- жах + гнів: ...als ich allein in meinem Atelier stand, plötzlich knieweich, und mich besann, überströmten mich Schreck und Zorn wie die neunte Welle, die endlich auf den leeren Strand flutet. "Heiners, das Schwein", sagte ich zu der Wand (там само: 140);

- агресивність: Er riß mich plötzlich ungestüm an den Haaren. "Kein Zopf mehr, keine Mähne..."

"Du tust mir weh", sagte ich (там само: 168);

- душевний біль (метафорично гіркота): “Wir werden aber seine Gründe prüfen, Ulrich ist kein Gegner".

"Noch nicht", sagte ich bitter (там само: 179);

- каяття: und Joachim kam zu mir, und ich lehnte mein Gesicht an sein Knie, stammelnd: "Mein Liebster, mein Einziger... Ich fühl mich wie eine betrogene Frau ... ich hatte kein Recht, ich weiß... ich fühl mich, als hätte er mir ein lebendiges Stück Fleisch rausgerissen..." (там само: 182). 
Відповідно до наведених прикладів емоції персонажів умовно поділяємо на три групи: негативні (несхвалення, розчарування, жалкування, зневага, смуток, нудьга, образа, невдоволення, страх, хвилювання (відносно помірне та інтенсивне), роздратування, нетерпіння, гнів, несправедливість, провина, антипатія, осуд, агресивність, душевний біль (метафорично гіркота), позитивні (інтерес, радість, подив, закоханість, ніжність, бажання, любов, сором, симпатія, каяття), нейтральні (безтурботність, спокій), при цьому деякі 3-поміж негативних (хвилювання) і позитивних (любов) емоцій характеризуються найвищим ступенем вияву. Критерієм поділу слугує модальність переживання персонажа в рамках предметної ситуації. Під переживанням розуміємо, слідом за І. Лисенковою, «психофізіологічний стан, у якому виявляється зацікавлене ставлення людини до когось/ чогось» (2019: 30).

Негативні переживання персонажів виникають через розбіжність між очікуваними й дійсними результатами (за Фестингером, 1999), позитивні задовольняють духовні потреби й інтереси персонажів (за Кириленко, 2007), нейтральні або врівноважені переживання повністю відповідають прагненням і уявленням персонажів про бажане (за Войтком, 1982). Емоційні патерни класифікуємо також на три групи переживань: амбівалентні (негативно-позитивні: гнів + подив, позитивно-негативні: інтерес + нечутливість), негативні (зневага, образа + погроза, нетактовність + приниження, жах + гнів), позитивні (любов + захоплення, інтерес + щастя).

Зіставляючи інвентарний та вихідний (Лук, 1982: 25) списки емоцій персонажів, зауважимо, що левова частка інвентарних негативних емоцій збігається із вихідними емоціями та виходить за межі теоретично можливих, як-от наприклад: несхвалення, жалкування, зневага, хвилювання, роздратування, несправедливість, провина, антипатія, осуд, агресивність. Емоції співчуття, сорому, каяття, як уже зазначалось вище, належать до позитивних переживань.

Загалом домінують негативні емоції та негативні емоційні патерни. Це ще раз підтверджує тезу дослідників про той факт, що негативні переживання відіграють більш важливу роль у житті людини, ніж позитивні (Приходько, 2001: 84), оскільки вони «сигналізують про загрозу або невдачу, зберігаються у пам'яті людини довше, ніж переживання, які виникають у ситуації позитивних наслідків» (Трофімова, 2014: 21). 


\section{Висновки}

Розгляд еліптичних речень як засобу вираження емоцій дає змогу виявити дві категорії феномену - авторську й персонажну та зробити висновок та зробити висновок, що функції авторських емоцій більш розмаїтті, ніж персонажних. При цьому персонаж переживає як емоції, так і емоційні патерни. Семантика емоцій та емоційних патернів персонажів багатогранна: негативні, позитивні, нейтральні, амбівалентні. Преференції тотожні негативним емоціям та емоційним патернам. Перспективним щодо подальших досліджень видається реконструкція парадигми емоцій, виражених еліптичними реченнями, в інших оповіданнях Б. Рейман, наприклад: "Die Frau am Pranger", "Kinder von Hellas", "Das Geständnis", "Ankunft im Alltag”, "Das grüne Licht der Steppen”, а також зіставна семантика емоцій авторки та персонажів.

\section{ЛІТЕРАТУРА}

1. Бабенко, Л. Г. (1989). Лексические средства обозначения эмоций в русском языке. Свердловск: Изд-во Урал. ун-та. 2. Бацевич, Ф. С. (2004). Основи комунікативної лінгвістики. Київ: Академія. 3. Безугла, Л. О.. Лінгвопрагматика дискримінаиіï у публіцистичному дискурсі. Харків: ФОП Лисенко І. Б. 4. Вежбицкая, А. (1999). Семантические универсалии и описание языков (А. Д. Шмелева, пер.). Москва: Радуга. 5. Войтко, В. І. (Ред.) (1982). Психологічний словник. Київ: Вища школа. 6. Воркачев, С. Г. (2003). Сопоставительная этносемантика телеономных концептов «любовь» и «счастье» (русско-английские параллели). Волгоград: Перемена. 7. Гамзюк, М. В. (2000). Емотивний компонент значення у процесі створення фразеологічних одиницъ: На матеріалі німецької мови. Київ: Вид. центр КДЛУ. 8. Изард, К. Э. (2008). Психология эмоций (В. Мисник, А. Татлыбаева, пер.). Санкт-Петербург: Питер. 9. Кириленко, Т. С. (2007). Психологія: емоційна сфера особистості. Київ: Либідь. 10. Лисенкова, І. П. (2019). Детермінанти емоційного розвитку дітей з когнітивними порушеннями. (Дис. ... д-ра психол. наук). Київ: Ін-т спеціальної педагогіки і психології ім. М. Ярмаченка НАПН України. 11. Лук, А. Н. (1982). Эмоции и личность. Москва: Знание. 12. Морозова, І. Б. (2009). Парадигматичний аналіз структури і семантики елементарних комунікативних одиниць у світлі гештальт-теорії в сучасній англійській мові. Одеса: Друкарський дім. 13. Орбан-Лембрик, Л. Е. (2004). Соціальна психологія. (Кн. 1: Соціальна психологія особистості і спілкування). Київ: Либідь. 14. Пименова, М. В. (2007). Концепт сердие: образ, понятие, символ. Кемерово: КемГУ. 15. Приходько, Г. І. (2001). Способи вираження оцінки в сучасній англійській мові. Запоріжжя: ЗДУ. 16. Романова, Н. В. (2013). Історія емотивної лексики німецької мови VIII - початку XXI століть. Київ: Вид. центр КНЛУ. 17. Романова, Н. В. (2019). Емоції у німецькомовних біблійних текстах Старого Заповіту. Херсон: Айлант. 18. Серякова, И. И. (2012). Невербальный знак коммуникаиии в англоязычных 
дискурсивных практиках. Киев: Изд. центр КНЛУ. 19. Трофімова, О. В. (2014). Фразеологія негативних емоцій в англійській та українській мовах. Донецьк: ДонНУ. 20. Фестингер, Л. (1999). Теория когнитивного диссонанса = A theory of cognitive dissonance (А. Анистратенко, И. Знаешева, пер.). Санкт-Петербург: Ювента. 21. Шаховский, В. И. (2008). Категоризация эмоций в тексико-семантической системе языка. Москва: Изд-во ЛКИ. 22. Kövecses, Z. (2004). Metaphor and Emotion. New York: Cambridge University Press. 23. Reimann, B. (2007). Die Geschwister. Berlin: Aufbau Taschenbuch Verlag. 24. Shevchenko, I., \& Gutorov, V. (2019). A cognitive-pragmatic perspective on apologies in English and Ukrainian discourse. Lege artis. Language yesterday, today, tomorrow, IV (2), 301-342. 25. Weitershaus, F.-W. (1998). Das neue große Vornamenbuch. München: Mosaik Verlag.

\section{REFERENCES}

1. Babenko, L. G. (1989). Leksicheskie sredstva oboznacheniya e’mocij v russkom yazyke [Lexical means of designation of emotions in Russian]. Sverdlovsk: Izd-vo Ural. un-ta [in Russian]. 2. Batsevich, F. S. (2004). Osnovy komunikatyvnoi linhvistyky [Bases of communication linguistic]. Kyiv: Akademiia [in Ukrainian]. 3. Bezuhla, L. R. \& Romanchenko, I. O. (2013). Linhvoprahmatyka dyskryminatsii u publitsystychnomu dyskursi [Lingvistic Pragmatic of discrimination in Newspaper Discourse]. Kharkiv: FOP Lysenko I. B. [in Ukrainian]. 4. Vezhbickaya, A. (1999). Semanticheskie universalii i opisanie yazykov [Semantic universals and description of languages] (A. D. Shmeleva, trans.). Moskva: Raduga [in Russian]. 5. Voitko, V. I. (Ed.) (1982). Psykholohichnyi slovnyk [Psycholigical dictionary]. Kyiv: Vyscha shkola [in Ukrainian]. 6. Vorkachev, S. G. (2003). Sopostavitel'naya e'tnosemantika teleonomnyx konceptov «lyubov' $i$ «schast'e» (russko-anglijskie paralleli) [Comparative ethnosemantics of concepts "love" and "happiness" (Russian-English parallels]. Volgograd: Peremena [in Russian]. 7. Hamziuk, M. V. (2000). Emotyvnyi component znachennia u protsesi stvorennia frazeolohichnykh odynyts: Na materiali nimetskoi movy [Emotive component meaning in process of creation of phraseological units: On the material of German]. Kyiv: Vyd. tsentr KSLU [in Ukrainian]. 8. Izard, K. E. (2008). Psixologiya e'mocij [Psychology of emotions] (V. Misnik, A. Tatlybaeva, trans.). Sankt-Petersburg: Pieter [in Russian]. 9. Kyrylenko, T. S. (2007). Psykholohiia: emotsiina sfera osobystosti [Psychology: emotional sphere of personality]. Kyiv: Lybid [in Ukrainian]. 10. Lysenkova, I. P. (2019). Determinanty emotsiinoho rozvytku ditei z kohnityvnymy porushenniamy [Determinants of emotional development of children with cognitive breaches]. Doctor's thesis. Kyiv: In-t spetsialnoi pedahohiky i psykholohii imeni Mykoly Iarmachenka NAPN Ukrainy [in Ukrainian]. 11. Luk, A. N. (1982). E'mocii i lichnost' [Emotions and Personality]. Moskva: Znanie [in Russian]. 12. Morozova, I. B. (2009). Paradyhmatychnyi analiz struktury I semantyky elementarnykh odynyts u svitli heshtalt-teorii $v$ suchasnii anhliiskii movi [Paradigm analysis of structure and semantics of elementary communicative units in the gestalt-theory in modern English]. Odessa: Drukarskyi dim [in Ukrainian]. 13. Orban-Lembryk, L. E. (2004). Sotsialna psykholohiia [Social Psychology]. (Vol. 1: Sotsialna psykholohiia osobystosti I spilkuvannia). Kyiv: Lybid [in Ukrainian]. 14. Pimenova, M. V. (2007). Koncept serdce: obraz, ponyatie, simvol [Concept HEART: image, notion, symbol]. Kemerovo: KemGU [in Russian]. 15. Prykhodko, H. I. (2001). Sposoby vyrazhennia otsinky $v$ suchasnii anhliiskii movi [Ways of convey of valuation in modern English]. Zaporizhzhia: ZDU [in Ukrainian]. 16. Romanova, N. V. (2013). Istoriia 
emoityvnoi leksyky nimetskoi movy VIII — pochatku XXI stolit [History of emotive vocabulary of German VIII - beginning XXI centuries]. Kyiv: Vyd. tsentr KNLU [in Ukrainian]. 17. Romanova, N. V. (2019). Emotsii u nimetskomovnykh bibliinykh tekstakh Staroho Zapovitu [Emotions in German biblical texts of the Old Testament]. Kherson: Ailant [in Ukrainian]. 18. Seryakiova, I. I. (2012). Neverbal'nyj znak kommunikacii v angloyazychnyx diskursivnyx praktikax [Non-verbal sign of communication in English discourse practices]. Kiev: Izd. centr KNLU [in Russian]. 19. Trofimova, O. V. (2014). Frazeolohiia nehatyvnykh emotsii v anhliiskii ta ukrainskii movakh [Phraseology of negative emotions in English and Ukrainian]. Donetsk: DonNU [in Ukrainian]. 20. Festinger, L. (1999). Teoriya kognitivnogo dissonansa $=$ A theory of cognitive dissonance [A theory of cognitive dissonance] (A. Anistratenko, I. Znaesheva, trans.). Sankt-Petersburg: Yuventa [in Russian]. 21. Shaxovskij, V. I. (2008). Kategorizaciya e'mocij v leksiko-semanticheskoj sisteme yazyka [Categorization of emotions in lexical-semantics system of language]. Moskva: Izd-vo LKI [in Russian]. 22. Kövecses, Z. (2004). Metaphor and Emotion. New York: Cambridge University Press [in English]. 23. Reimann, B. (2007). Die Geschwister [The siblings]. Berlin: Aufbau Taschenbuch Verlag [in German]. 24. Shevchenko, I., \& Gutorov, V. (2019). A cognitive-pragmatic perspective on apologies in English and Ukrainian discourse. Lege artis. Language yesterday, today, tomorrow, IV (2), 301-342 [in English]. 25. Weitershaus, F.-W. (1998). Das neue große Vornamenbuch [New big first name book]. München: Mosaik Verlag [in German].

Романова Наталя Василівна - доктор філологічних наук, доцент, професор кафедри німецької та романської філології, Херсонський державний університет; вул. Університетська, 27, м. Херсон, 73000, Україна.

\author{
Tel.: 066-55-72-417 \\ E-mail: vissensvelt@gmail.com \\ http://orcid.org/0000-0002-7444-3811
}

Romanova Natalia Vasylivna - Doctor of Philological Sciences, Docent, Professor at the Department of German and Romance Philology, Kherson State University; Universytetska Str. 27, Kherson, 73000, Ukraine.

Надійшла до редакції 08 вересня 2020 року

\title{
CITATION
}

ДСТУ 8302:2015: Романова Н. В. Еліптичні речення як засіб вираження емоцій (на матеріалі оповідання Б. Рейман “Die Geschwister"). Лінгвістичні дослідження: $з б$. наук. пр. Харк. нац. пед. ун-ту імені Г. С. Сковороди. Харків, 2020. Вип. 53. С. 105-116. DOI: https://doi.org/10.34142/23127546.2020.53.10

APA: Романова, Н. В. (2020). Еліптичні речення як засіб вираження емоцій (на матеріалі оповідання Б. Рейман “Die Geschwister"). Лінгвістичні дослідження, 53, 105-116. DOI https://doi.org/10.34142/23127546.2020.53.10 